\title{
Productive and reproductive performance and metabolic profiles of ewes supplemented with hydroponically grown green wheat (Triticum aestivum $\mathrm{L}$.) ${ }^{\text {is }}$
}

\author{
M. Guerrero-Cervantes ${ }^{a}$, M.A. Cerrillo-Soto ${ }^{a}$, A. Plascencia ${ }^{b}$, A.Z.M. Salem ${ }^{c, *}$, \\ A. Estrada-Angulo ${ }^{\mathrm{d}}$, F.G. Rios-Rincón ${ }^{\mathrm{d}}{ }^{\text {, J.M. }}{ }^{\text {L Luginbuhle }}{ }^{\mathrm{e}}$, H. Bernal-Barragán ${ }^{\mathrm{f}}$, \\ A.L. Abdallag ${ }^{g}$ \\ a Facultad de Medicina Veterinaria y Zootecnia, Universidad Juárez del Estado de Durango, Durango, Mexico \\ b Instituto de Investigaciones en Ciencias Veterinarias, Universidad Autónoma de Baja California, Mexicali, B.C., Mexico \\ c Facultad de Medicina Veterinaria y Zootecnia, Universidad Autónoma del Estado de México, Toluca, Mexico \\ d Facultad de Medicina Veterinaria y Zootecnia. Universidad Autónoma de Sinaloa, Culiacán, Sinaloa, Mexico \\ e College of Agriculture and Life Sciences, North Carolina State University, USA \\ f Facultad de Agronomía, Universidad Autónoma de Nuevo León, Monterrey, Nuevo León, Mexico \\ g Centro de Energia Nuclear na Agricultura, Universidade de São Paulo, Brazil
}

\section{A R T I C L E I N F O}

\section{Article history:}

Received 2 April 2016

Received in revised form 8 September 2016

Accepted 10 September 2016

\section{Keywords:}

Plasma metabolites

Female lambs

Hydroponic wheat

Metabolic hormones

Reproductive performance

\begin{abstract}
A B S T R A C T
Twenty six Katahdin ewes (i.e., female lambs from breeding to 2 mo of their 1 st lactation) were used in a completely randomized design (13/treatment) to evaluate effects of replacement of dietary dry-rolled corn grain (DRC) and cottonseed meal (CSM) with hydroponically grown whole plant green wheat (HGW; Triticum aestivum $\mathrm{L}$.) on productive parameters and blood metabolites during mating, gestation and lactation, and on body weight (BW) gain of their lambs in their 1 st 60 days of age. The gestation diet contained $70 \%$ oat hay, $20 \%$ rolled corn grain and $10 \%$ cottonseed meal, while the lactation diet contained $50 \%$ oat hay, $20 \%$ DRC and 30\% CSM. Treatments consisted of total replacement of DRC and CSM with HGW in the gestation diet, while in the lactation diet HGW replaced $100 \%$ of the DRC and $33 \%$ of the CSM. There were no diet effects on reproductive parameters, and substitution of DRC and CSM with HGW did not affect dry matter intake during gestation and lactation. The BW gain of the lambs that were fed HGW did not differ from controls in the first 2 months of gestation, while it was lower $(P<0.05)$ at the last 3 months of gestation. Feeding HGW did not affect birth BW of lambs or subsequent BW gains through 60 days of age. Plasma non-esterified fatty acids (NEFA) were not affected by the diets fed during gestation, but were $56 \%$ lower $(P<0.05)$ at day 60 of lactation. Plasma glucose was only lower $(P<0.05)$ at day 90 of gestation, and blood urea nitrogen was only lower $(P<0.05)$ at day 30 of lactation. There were no effects of diets on plasma insulin, cortisol or progesterone during gestation and lactation. Hydroponically grown green wheat is a suitable substitute for a portion of the DRC and CSM in ewes diets during gestation and lactation without negative effects.
\end{abstract}

(c) 2016 Elsevier B.V. All rights reserved.

\footnotetext{
th This research was supported by PROMEP-SEP(México): Impacto productivo y económico de subproductos agroindustriales y forrajes no convencionales en la alimentación de rumiantes and by ANKOM Technology Inc. (Macedon, NY). Technical assistance provided by Dr. D.M. Hallford for hormone analyses is recognized.

* Corresponding author.

E-mail addresses: asalem@yahoo.com, asalem70@hotmail.com (A.Z.M. Salem).
} 


\section{Introduction}

Inclusion of high levels of concentrate in the diets of late gestation and lactating ewes to improve productive and reproductive performance is a common practice. However cost-effective alternate feeding strategies for small ruminants must be developed and evaluated in order to counteract sustainability issues of feeding them concentrate feeds (Alexandre and Mandonnet, 2005).

Hydroponically grown green forages are a potential high feed quality feedstuff in arid and semiarid regions of the world (Al-Faraki and Al-Hashimi, 2012). The nutritive value and fermentative characteristics of hydroponically grown forages positively influenced the performance of late gestation and lactating ewes (Herrera et al., 2010; Gebremedhin, 2015). Earlier investigations emphasized effects of dietary quality on endocrine and metabolic profiles in ewes during pregnancy and lactation (Lemley et al., 2014; Vonnahme et al., 2013). However adequate nutritional status of ewes is associated with favorable productive and reproductive performance whereby blood glucose, non-esterified fatty acids (NEFA) and blood urea nitrogen (BUN) are utilized to sustain a desirable protein and energy balance in ewes during gestation and lactation (Hatfield et al., 1999). Changes in metabolic hormones, such as insulin, play an important role in metabolic adaptation to changes in body weight (BW) and body condition while providing diagnostic information to evaluate ewe nutritional status (Caldeira et al., 2007). Cortisol may be particularly important in this regard as it is the predominant glucocorticoid in sheep blood and has been used as a reliable physiological endpoint to determine ewe responses to a variety of physiological, physical and environmental stress (Moolchandani et al., 2008).

A paucity of information is available with respect to the metabolic profile and performance during mating, gestation and lactation of ewes fed diets containing hydroponically grown green wheat (HGW). Thus this experiment was conducted to determine effects of replacement of dry-rolled corn (DRC) and cottonseed meal (CSM) by HGW in an oat hay-based diet on the metabolic profile as well as the productive and reproductive performance of Katahdin female lambs.

\section{Materials and methods}

\subsection{Study site}

Animal management procedures were within guidelines of locally approved techniques for animal use and care. The experiment was conducted at the experimental facilities of the Facultad de Medicina Veterinaria y Zootecnia of the Universidad Juárez del Estado de Durango (México), located at $24^{\circ} 28^{\prime} \mathrm{N}$ and $104^{\circ} 40^{\prime} \mathrm{W}$ and at an altitude of $1890 \mathrm{~m}$. The climate is classified as Bs1 (k)(w), considered as dry temperate with a mean annual temperature and rainfall of $17.5^{\circ} \mathrm{C}$ and $450 \mathrm{~mm}$, respectively.

\subsection{Production of hydroponic green wheat}

Wheat seeds (variety Anahuac) were rinsed three times with water, disinfected with a 5\% sodium hypochlorite solution, soaked in water for $24 \mathrm{~h}$ in a plastic container, and transferred to a perforated container for $24 \mathrm{~h}$. Seeds were sown in $40 \times 40 \mathrm{~cm}$ perforated plastic trays using 800 g of germinating seeds per tray, which were then placed in a $5.25 \times 5.25 \mathrm{~m}$ greenhouses. Growing forage was irrigated 5 times/day for $2 \mathrm{~min}$. The green wheat forage was harvested $10 \mathrm{~d}$ post- germination (Herrera et al., 2010).

\subsection{Animals, management, and treatments}

Katahdin ewes (i.e., female lambs from breeding to 2 mo of their 1st lactation; hereafter referred to simply as 'ewes' to differentiate them from their lambs which are referred to as 'lambs') with an initial BW of $32.4 \pm 3.3 \mathrm{~kg}$ and $9.0 \pm 1.5 \mathrm{mo}$ of age were fed for $8 \mathrm{mo}$ in order to evaluate inclusion of HGW during mating, gestation and lactation. The experiment consisted of 1 mo of mating, 5 mo of gestation and 2 mo of lactation. Three weeks previous to start the experiment, all ewes were dewormed (Valbazen, Pfizer ${ }^{\circledR}$, Mexico City, Mexico) and injected with $1 \times 10^{6}$ IU vitamin A (Synt-ADE, Fort Dodge Animal Health, México).

To synchronize estrus, the ewes were treated with intra-vaginal sponges containing 65 mg medroxy-progesterone. When the sponge was removed after 14 d, 400 IU PMSG (Folligon ${ }^{\circledR}$ : Shering-Plough Animal Health) were administered intramuscularly. After that, ewes were divided into 4 groups and exposed to 4 Katahdin rams (i.e., 1 ram/group). Rams were marked on the chest with a colored crayon to monitor and record mating. Once mating was completed, ewes were randomly divided into 2 groups of 13 and housed in individual $2 \times 1 \mathrm{~m}$ pens with continuous access to water and a supplement of vitamins and minerals.

Two types of diets were fed during the experiment, being a gestation diet during mating and gestation, and a lactation diet during the 2 mo of lactation. The gestation diet contained (g/kg DM): 700 oat hay, 200 DRC, 100 CSM, while the lactation diet contained (g/kg DM): 500 oat hay, 200 DRC, 300 CSM. The HGW diet during gestation (HGW-G) consisted of total replacement of DRC and CSM by $300 \mathrm{~g} / \mathrm{kg}$ DM of HGW (corresponding to $2 \mathrm{~kg}$ as fresh HGW). Similarly, during lactation (HGW-L), $300 \mathrm{~g} / \mathrm{kg}$ DM of HGW (2 kg as fresh) was totally replaced with DRC and partially with CSM (i.e., $100 \mathrm{~g} / \mathrm{kg}$ DM of $300 \mathrm{~g} / \mathrm{kg} \mathrm{DM})$. The dietary ingredients and experimental diets are in Table 1. 
Table 1

Ingredients and chemical analysis of dietary ingredients and experimental diets. ${ }^{1}$

\begin{tabular}{|c|c|c|c|c|c|c|c|c|}
\hline & \multirow[t]{2}{*}{ Oat hay } & \multirow{2}{*}{$\begin{array}{l}\text { Hydroponic } \\
\text { Green wheat }\end{array}$} & \multirow[t]{2}{*}{ Rolled corn } & \multirow[t]{2}{*}{ Cottonseed meal } & \multicolumn{2}{|c|}{ Mating-GestationDiet } & Lactation & Diet \\
\hline & & & & & $\mathrm{Ctr}-\mathrm{G}^{1}$ & $\mathrm{HGW}-\mathrm{G}^{2}$ & Crt- $\mathrm{L}^{3}$ & HGW-L ${ }^{4}$ \\
\hline \multicolumn{9}{|l|}{ Ingredient, g/kg DM } \\
\hline Oat hay & & & & & 700 & 700 & 500 & 500 \\
\hline Hydroponic green wheat & & & & & 0 & 300 & 0 & 300 \\
\hline Rolled corn & & & & & 200 & 0 & 200 & 0 \\
\hline Cotton seed meal & & & & & 100 & 0 & 300 & 200 \\
\hline \multicolumn{9}{|l|}{ Chemical analysis, g/kg DM } \\
\hline Dry matter & 905 & 150 & 886 & 899 & 901 & 694 & 899 & 692 \\
\hline Organic matter & 926 & 969 & 986 & 935 & 911 & 882 & 917 & 889 \\
\hline Crude protein & 97 & 175 & 73 & 415 & 124 & 119 & 188 & 182 \\
\hline Neutral detergent fiber & 688 & 568 & 150 & 316 & 543 & 654 & 469 & 588 \\
\hline Acid detergent fiber & 365 & 258 & 20 & 154 & 275 & 335 & 233 & 293 \\
\hline Acid detergent lignin & 38 & 12 & 2.4 & 42 & 31 & 31 & 32 & 32 \\
\hline Predicted $\mathrm{NE}_{\mathrm{m}}, \mathrm{Mcal} / \mathrm{kg}^{2}$ & 15.8 & 15.5 & 21.1 & 18.0 & - & - & - & - \\
\hline
\end{tabular}

1 Ctr-G, control diet during gestation; HGW-G, hydroponic green wheat diet during gestation; Ctr-L, control diet during lactation; HGW-L, hydroponic green wheat diet during lactation.

$2 \mathrm{NE}_{\mathrm{m}}$ (net energy for maintenance, $\mathrm{Mcal} / \mathrm{kg}$ ) $=0.255 \mathrm{ADF}+0.0325 \mathrm{CP}+0.0704 \mathrm{EE}+0.034 \mathrm{NFE}-1.18$, where nutrient concentration are expressed as $\mathrm{g} / 100 \mathrm{~g}$, $\mathrm{EE}$ is ether extract and NFE (nitrogen free extract) is equivalent to 100-(ADF + CP + EE + ash) - Zinn and Plascencia (1993).

Ewes were individually fed and daily feed allocations to each pen were adjusted to allow minimal (i.e., $<5 \%$ ) feed refusals in the feed bunk. The amounts of feed offered and feed refused were weighed daily. Lambs were provided fresh feed at 0900 and $1500 \mathrm{~h}$ daily. Feed bunks were visually assessed between 0840 and $0850 \mathrm{~h}$ each morning, refusals were collected and weighed and individual feed intake was determined. Ewes were weighed monthly during the gestation and lactation periods, whereas lambs were weighed at birth and every $15 \mathrm{~d}$ thereafter through $60 \mathrm{~d}$ of life.

\subsection{Blood sampling and laboratory analyses}

Samples were collected monthly by jugular venipuncture before the morning feeding into vacutainer tubes. Samples were centrifuged at $500 \mathrm{~g}$ for $20 \mathrm{~min}$ at $4{ }^{\circ} \mathrm{C}$ and plasma was stored at $-20^{\circ} \mathrm{C}$ before analysis for glucose, non-esterified fatty acids (NEFA) and blood urea nitrogen (BUN). Glucose, NEFA and BUN were assayed using commercial kits (Randox Laboratories LTD, United Kingdom) by spectrophotometric procedures (SpectronicGenesys 2PC). The sensitivity of the assays were $0.013 \mathrm{mmol} / \mathrm{L}$ for glucose, $0.072 \mathrm{mmol} / \mathrm{L}$ for NEFA, and $2.13 \mathrm{mmol} / \mathrm{L}$ for BUN. The intra- and inter-assay coefficient of variation were $3.8 \%$ and $4.4 \%$ for glucose, $4.7 \%$ and $5.5 \%$ for NEFA, and $4.5 \%$ and 5.8 for BUN.

Cortisol (Kiyma et al., 2004), progesterone (Schneider and Hallford, 1996) and insulin (Camacho et al., 2012) were by RIA using components of commercial kits previously validated for use in ruminant serum (Coat-A-count, Siemens Healthcare Diagnostics, Inc., Los Angeles, CA, USA). Sensitivity of the assays were $15 \mathrm{nmol} / \mathrm{L}$. Intra- and inter-assay variations were $3.5 \%$ and $4.6 \%$ for cortisol and $8.9 \%$ and $2.1 \%$ for progesterone. The insulin CV was $4.17 \%$.

\subsection{Feed analyses}

Diets offered and refused were ground to pass a $1 \mathrm{~mm}$ screen and assayed for dry matter (DM), ash, and N (AOAC, 1994). Neutral detergent fiber (NDF), acid detergent fiber (ADF) and sulfuric acid lignin assays were by Van Soest et al. (1991).

\subsection{Calculations}

Productive performance parameters were assessed as:

Fertility $=$ (numberofpregnantewes/totalewes $) \times 100$,

Prolificacy $=$ (numberoflambsbornalive/numberoflambsborn $) \times 100$,

Fecundity $=$ (numberoflambsborn/totalewes $) \times 100$,

Lambingrate $=($ numberoflambsbornalive/totalewes $) \times 100$, and

Weaningrate $=$ fecundity/weaningsurvival

Daily BW gain was determined by subtracting the initial from the final BW and dividing by the number of days on feed. 
Table 2

Dry matter intake and daily weight gain of Katahdin young ewes fed hydroponic green wheat during gestation and lactation. $(n=13$ ).

\begin{tabular}{|c|c|c|c|c|}
\hline & Diet $^{1}$ & & SE & $P$ \\
\hline & $\mathrm{Ctr}$ & HGW & & \\
\hline \multicolumn{5}{|l|}{ Dry matter Intake, $\mathrm{g} / \mathrm{d}$} \\
\hline Early gestation -first 2 months & 1121 & 1206 & 8.6 & NS \\
\hline Late gestation -last 3 months & 1162 & 1210 & 8.0 & NS \\
\hline Gestation & 1140 & 1209 & 8.1 & NS \\
\hline Lactation & 1201 & 1188 & 10.1 & NS \\
\hline \multicolumn{5}{|l|}{ Daily weight gain, g/d } \\
\hline Early gestation -first 2 months & 65.4 & 52.2 & 2.5 & NS \\
\hline Late gestation -last 3 months & 146.7 & 90.5 & 3.0 & 0.032 \\
\hline Gestation & 90.85 & 73.62 & 2.3 & NS \\
\hline Lactation & -77.46 & -123.77 & 7.7 & NS \\
\hline
\end{tabular}

1 Diets contained 0\% (control diet - Ctr) or 30\% of hydroponic green wheat (HGW diet) during gestation and lactation periods.

$\mathrm{SE}=$ Standard error.

NS = not significant $(P>0.05)$.

Table 3

Reproductive performance (\%) of Katahdin young ewes fed hydroponic green wheat (HGW) during mating, gestation and lactation. ${ }^{1}(n=13)$.

\begin{tabular}{llll}
\hline & Diet $^{2}$ & & $P$ \\
\cline { 2 - 4 } & $\mathrm{Ctr}$ & HGW & NS \\
\hline Fertility & 84.6 & 84.6 & NS \\
Prolificacy & 145.0 & 140.0 & NS \\
Fecundity & 118.0 & 118.0 & NS \\
Lambingrate & 100.0 & 107.6 & NS
\end{tabular}

1 Chi-square test (Steel et al., 1997).

2 Diets contained 0\% (control diet - Ctr) or 30\% of hydroponic green wheat (HGW diet) during gestation and lactation periods.

$\mathrm{SE}=$ Standard error.

NS = not significant $(P>0.05)$.

\subsection{Data analyses}

Fertility, prolificacy, fecundity, and lambing and weaning rate data were analyzed using a chi-square test (Steel et al., 1997). Variables related to DM intake and daily BW gain were analyzed according to a completely randomized design using initial BW as a covariate using the GLM procedure of the Statistical Analysis System (SAS, 2003) with means separated with Tukey's multiple range test (Steel et al., 1997).

Glucose, NEFA, BUN, cortisol, progesterone and insulin serum concentrations were analyzed using a completely randomized design with 'month' as a repeated measure (Littell et al., 1996) using the MIXED procedure of SAS (2003) and the "Repeated and Random" option. The statistical model included diet, month and the diet x month interaction as fixed effects, whereas ewe within diet was a random effect.

In all cases, least squares means and standard error are reported and differences were accepted as significant if $P<0.05$ with trends to differences accepted if $P<0.10$.

\section{Results}

Substitution of dietary DRC and CSM with HGW did not affect DM intake during gestation and lactation, which averaged $1174 \pm 8$ and $1195 \pm 10 \mathrm{~g} / \mathrm{d}$. Although BW gains of female lambs that were fed with HGW did not differ from the controls in the two first months of gestation, the lower BW gain (i.e., 90.5 versus $146.7 \mathrm{~g} / \mathrm{d} ; P<0.05$ ) in the last 3 mo of gestation for the ewes fed HGW decreased the final BW gain (i.e., 73 versus $91 \mathrm{~g} / \mathrm{d}$; $P<0.05$ ) during gestation. However, this did not affect the birth weight (average $3.1 \mathrm{~kg}$ ) of the lambs and subsequent BW gains (167 versus $175 \mathrm{~g} / \mathrm{d}$ ) through 60 days of age. There were no diet effects on reproductive parameters (Tables 2-4).

Plasma NEFA was not affected by diets during gestation, but was $56 \%$ lower $(P<0.05)$ at day 60 of lactation. Plasma glucose decreased by $30.9 \%(P<0.05)$ only at day 90 of gestation with no differences at day 150 . Blood urea $\mathrm{N}$ decreased $25.9 \%(P<0.05)$ at day 30 of lactation (Table 5). Except for day 30differences in concentrations of cortisol and insulin, there were no differences between diets in plasma concentrations of insulin, cortisol or progesterone during gestation and lactation (Table 6). 
Table 4

Gestation length, ewe's weight at lambing and lamb birth weight from Katahdin young ewes fed hydroponic green wheat (HGW) during gestation and lactation. $(n=13)$.

\begin{tabular}{|c|c|c|c|c|}
\hline & \multicolumn{2}{|l|}{ Diet $^{1}$} & \multirow[t]{2}{*}{ SE } & \multirow[t]{2}{*}{$P$-value } \\
\hline & Ctr & HGW & & \\
\hline Gestationl ength, days & 153.9 & 154.7 & 0.31 & NS \\
\hline Ewe weight at lambing, kg & 39.9 & 36.0 & 0.80 & NS \\
\hline \multicolumn{5}{|l|}{ Lamb weight, kg } \\
\hline At birth & 3.1 & 3.1 & 0.11 & NS \\
\hline 15 days of age & 6.6 & 5.4 & 0.22 & NS \\
\hline 30 days of age & 8.7 & 7.7 & 0.42 & NS \\
\hline 45 days of age & 11.5 & 10.4 & 0.64 & NS \\
\hline 60 days of age & 13.6 & 13.1 & 0.66 & NS \\
\hline Daily BW gain, g & 175.0 & 167.0 & 0.73 & NS \\
\hline
\end{tabular}

1 Diets contained 0\% (control diet - Ctr) or 30\% of hydroponic green wheat (HGW diet) during gestation and lactation periods.

$\mathrm{SE}=$ Standard error

NS = not significant $(\mathrm{P}>0.05)$.

Table 5

Plasma glucose and non-esterified fatty acid (NEFA) and urea nitrogen concentrations (mmol/L) in Katahdin young ewes fed hydroponic green wheat (HGW) during gestation and lactation. $(n=13)$.

\begin{tabular}{|c|c|c|c|c|}
\hline & \multicolumn{2}{|l|}{$\operatorname{Diet}^{1}$} & \multirow[t]{2}{*}{ SE } & \multirow[t]{2}{*}{$P$} \\
\hline & $\mathrm{Ctr}$ & HGW & & \\
\hline \multicolumn{5}{|c|}{ During gestation $^{2}$} \\
\hline \multicolumn{5}{|l|}{ Glucose } \\
\hline Day 90 & 4.2 & 2.9 & 0.16 & 0.024 \\
\hline Day 120 & 3.3 & 2.9 & 0.16 & NS \\
\hline Day 150 & 2.5 & 2.2 & 0.16 & NS \\
\hline \multicolumn{5}{|l|}{ NEFA } \\
\hline Day 90 & 0.46 & 0.38 & 0.12 & NS \\
\hline Day 120 & 0.41 & 0.47 & 0.12 & NS \\
\hline Day 150 & 0.74 & 1.07 & 0.12 & NS \\
\hline \multicolumn{5}{|c|}{ During lactation ${ }^{3}$} \\
\hline \multicolumn{5}{|l|}{ NEFA } \\
\hline Day 30 & 1.40 & 1.25 & 0.121 & NS \\
\hline Day 60 & 0.84 & 0.37 & 0.120 & 0.031 \\
\hline \multicolumn{5}{|c|}{ Urea nitrogen } \\
\hline Day 30 & 4.70 & 3.48 & 0.591 & 0.042 \\
\hline Day 60 & 4.78 & 5.08 & 0.592 & NS \\
\hline
\end{tabular}

1 Diets contained 0\% (control diet - Ctr) or 30\% of hydroponic green wheat (HGW diet) during gestation and lactation periods.

2 Day of gestation $\mathrm{x}$ diet interaction $(P<0.001)$.

3 Day of lactation $\mathrm{x}$ diet interaction $(P<0.001)$.

$\mathrm{SE}=$ Standard error

NS = not significant $(P>0.05)$.

\section{Discussion}

\subsection{Dry matter intake and daily gain}

Differences in DM intake might have been related to variations in nutrient composition of the experimental diets, as well as differences in the initial BW of the ewes. Average intake of CP in ewes fed HGW-G and Control diets were similar, but the former had $\sim 18 \%$ higher NDF intake. Nonetheless, increasing the dietary NDF by $\sim 17 \%$ by replacing DRC and CSM with HGW in the gestation diet did not affect DM intake. Van Soest (1994) suggested that DM intake is controlled by physiological factors which respond to the energy level of the diet. As replacement of DRC and CSM by HGW in the gestation diet decreased its energy density by $\sim 6 \%$, the combination of increased NDF level and decreased diet energy density were likely the main factors that affected DM intake in late gestation (Foster et al., 2009). In spite of similar DM intakes among dietary treatments, the reason for the lower BW gain in ewes fed HGW is not clear. Rattay et al. (1982) indicated that herbage mass promoted lower ewe BW gains in late pregnancy, and HGWís inherent nutritional characteristics may result in lower BW gains in young ewes. Moreover, the high digestibility of hydroponically grown forages (Herrera et al., 2010; Dung et al., 2010) may support our view that a probable nutritive imbalance diverted nutrients away from productive purposes.

Although replacements of DRC and CSM with HGW decreased net energy for maintenance $\sim 15 \%$, this replacement did not affect the BW gain of the lambs. This absence of difference in BW gain during the first 2 mo of lactation could be due to higher mobilization of tissue in the female lambs fed HGW-L diets. 
Table 6

Serum cortisol, progesterone and insulin concentrations $(\mathrm{ng} / \mathrm{mL})$ in Katahdin young ewes fed hydroponic wheat during gestation and lactation. $(n=13)$.

\begin{tabular}{|c|c|c|c|c|}
\hline & \multicolumn{2}{|l|}{ Diet $^{1}$} & \multirow[t]{2}{*}{ SE } & \multirow[t]{2}{*}{$P$} \\
\hline & $\overline{\mathrm{Ctr}}$ & $\overline{H G W}$ & & \\
\hline \multicolumn{5}{|c|}{ During gestation } \\
\hline \multicolumn{5}{|c|}{ Cortisol } \\
\hline Day 30 & 12.42 & 17.03 & 1.86 & 0.021 \\
\hline Day 60 & 6.21 & 9.81 & 1.86 & NS \\
\hline Day 90 & 5.77 & 7.11 & 1.86 & NS \\
\hline Day 120 & 8.93 & 10.31 & 1.86 & NS \\
\hline Day 150 & 8.45 & 8.48 & 1.86 & NS \\
\hline $\mathrm{SE}$ & 1.04 & 1.04 & & \\
\hline \multicolumn{5}{|c|}{ Progesterone } \\
\hline Day 30 & 5.95 & 5.85 & 2.60 & NS \\
\hline Day 60 & 4.53 & 4.03 & 2.60 & NS \\
\hline Day 90 & 7.89 & 5.95 & 2.60 & NS \\
\hline Day 120 & 15.36 & 10.53 & 2.60 & NS \\
\hline Day 150 & 20.10 & 16.34 & 2.60 & NS \\
\hline SE & 1.73 & 1.73 & & \\
\hline \multicolumn{5}{|l|}{ Insulin } \\
\hline Day 30 & 0.25 & 0.16 & 0.06 & 0.031 \\
\hline Day 60 & 0.36 & 0.44 & 0.06 & NS \\
\hline Day 90 & 0.41 & 0.43 & 0.06 & NS \\
\hline Day 120 & 0.28 & 0.45 & 0.06 & NS \\
\hline Day 150 & 0.23 & 0.20 & 0.06 & NS \\
\hline SE & 0.03 & 0.03 & & \\
\hline \multicolumn{5}{|c|}{ During lactation } \\
\hline \multicolumn{5}{|l|}{ Cortisol } \\
\hline Day 30 & 8.71 & 7.32 & 1.26 & NS \\
\hline Day 60 & 8.21 & 6.88 & 1.26 & NS \\
\hline SE & 0.89 & 0.89 & & \\
\hline \multicolumn{5}{|c|}{ Progesterone } \\
\hline Day 30 & 0.58 & 0.79 & 0.28 & NS \\
\hline Day 60 & 0.29 & 0.72 & 0.28 & NS \\
\hline SE & 0.40 & 0.40 & & \\
\hline \multicolumn{5}{|l|}{ Insulin } \\
\hline Day 30 & 0.27 & 0.22 & 0.05 & NS \\
\hline Day 60 & 0.49 & 0.43 & 0.05 & NS \\
\hline $\mathrm{SE}$ & 0.04 & 0.04 & & \\
\hline
\end{tabular}

${ }^{1}$ Diets contained $0 \%$ (control diet - Ctr) or 30\% of hydroponic green wheat (HGW diet) during gestation and lactation periods.

$\mathrm{SE}=$ Standard error.

NS = not significant $(\mathrm{P}>0.05)$

\subsection{Fertility, fecundity, prolifacy, lambing and weaning rates}

The dietary treatments examined did not impact reproductive performance, and our high fecundity rates are superior to those reported by Hamadeh et al. (1998), which might be due to differences in nutrition, lack of abortion, stillbirth and death of pregnant ewes (Melaku et al. (2004). Inclusion of HGW and concentrate feeds did not affect prolificacy rates. Nevertheless, our values are in agreement with Mireles et al. (2011) who indicated normal prolificacy rates of $150 \%$.

Weaning rates are an important parameter that impacts profitability in sheep operations (Segura et al., 1996), but there were no diet impacts on our lamb weaning rates. Many groups have indicated that lamb survival from birth to weaning is closely related to the nutritional status of the ewe throughout pregnancy. For example, body condition and BW of the ewe, milk production, ewe pregnancy rank and size of lamb at birth strongly influence weaning rates (Kenyon et al., 2009). Thus, our results indicate that the level of nutrition offered to our ewes was not limiting weaning rates.

\subsection{Gestation length, ewe live weight at lambing and lamb birth weight}

The ewe gestation period averaged $154.3 \mathrm{~d}$, which suggests $\sim 1.5$ parturitions annually. Gardner et al. (2007) suggested that ewe body condition prior to pregnancy and late gestational energy intake are important determinants of lamb birth weight. In our study, inclusion of HGW did not affect newborn lamb birth weight ( $3.1 \mathrm{~kg}$ for both dietary treatments). Nonetheless, the BW of the lambs are within the $2.6-3.2 \mathrm{~kg}$ range of Vergara et al. (2006), who suggested an adequate maternal nutrition profile in female lambs fed both diets.

Ewe diet had no effect on BW gain of their lambs, while lamb BW was higher than reported by Godfrey and Dodson (2003). The pre-weaning lamb BW supports the hypothesis that use of HGW in ewe diets has the potential to improve the growth rate of traditionally managed sheep by improving ewe nutrition during pregnancy. 


\subsection{Serum metabolites during gestation and lactation}

The nutrient requirements of ewes increases during late pregnancy due to rapid fetal growth. If ewes do not receive at least half of their required energy during this period, fat depots are mobilized in large quantities (Braun et al., 2010). In our study plasma glucose differed among treatments at $90 \mathrm{~d}$ of gestation, although they had a tendency to decrease at the end of gestation in female lambs fed both diets. According to Firat and Özpinar (2002), low glucose during pregnancy is associated with fetus development and mobilization of maternal glucose for fetal blood circulation. Lower glucose in ewes fed the HGW diet at $90 \mathrm{~d}$ make it difficult to draw clear conclusions. Moreover, HGW diets tended to result in lower glucose in female lambs in all periods.

When ruminants are fed palatable diets that are high in bulk and low in energy, DM intake is limited by restriction of in digestive tract capacity (Mertens, 1994). The very high water content in HGW, as well as the low physical capacity of the rumen due to the expanding uterus might have contributed to the lower glucose levels in female lambs fed HGW. Nonetheless, low levels of glucose in mid gestation had little influence on lamb birth BW (Gardner et al., 2007). In the first 2 mo of lactation plasma glucose was not affected by diet, and remained constant, which is consistent with Firat and Özpinar (2002). Moreover, higher energy requirements during early lactation would tend to a negative energy balance wherein elevated plasma free fatty acid occurs during pre-partum and at parturition (Block et al., 2001). Such a scenario was noticeable in our study as high NEFA concentrations during the first $30 \mathrm{~d}$ of lactation, which is consistent with Karapehlivan et al. (2007), and also supported by Russel (1984) who indicated that plasma NEFA concentrations above $1.0 \mathrm{mmol} / \mathrm{L}$ are a threshold indicating onset of a catabolic status.

The BUN concentration is utilized to evaluate $\mathrm{N}$ metabolism. Our BUN remained constant throughout the gestation period, and within normal ranges for this period compared to reference values (Kaneko et al., 2008). However during the 2nd mo of lactation BUN levels were higher due to reduced milk production, thereby agreeing with Karapehlivan et al. (2007).

\subsection{Hormonal profile during gestation and lactation}

Activity of the hypothalamic-pituitary-adrenal axis, as measured by levels of Adrenocorticotrope hormone and cortisol has been used as a stress index (Squires, 2010). Except for early gestation, when values varied between 12.4 and $17.0 \mathrm{ng} / \mathrm{mL}$, plasma concentrations of cortisol did not show a profile associated with aversive situations of stress. Levels of cortisol were considerably lower than those reported by Caroprese et al. (2010) in Comisana ewes. Knott et al. (2010) indicated that sheep might display low cortisol concentrations owing to insulin-induced hypoglycemia and reported a close relationship among circulating cortisol concentrations and feed efficiency, with less efficient sheep having higher circulating cortisol concentrations. In our study a stress scenario was not evident during gestation or lactation based upon normal values of $22.4 \mathrm{ng} / \mathrm{mL}$ for sheep.

Although no differences occurred in serum progesterone concentrations among treatments, values were higher during the 4th and 5th mo compared to the first 3 mo of gestation. Our serum progesterone concentrations were superior to those reported for other ewe breeds (e.g., O'Doherty and Crosby, 1996; Mandiki et al., 2002). However, there is a paucity of information regarding serum progesterone levels of pregnant Katahdin lambs. Since there were no differences in progesterone concentrations among treatments during gestation, we conclude that the dietary treatments did not differ enough to produce a variation in the $\mathrm{P} 4$ profile during gestation.

As serum insulin levels are directly related to DM intake (Squires, 2010), the decrease in plasma insulin in the last month of gestation and at the beginning of lactation might reflect a reduction in DM intake of the ewes in both periods. Regnault et al. (2004) also reported a decline in maternal insulin and basal glucose concentrations as ovine gestation advanced, whereas Kiyma et al. (2004) observed the same pattern in ewes subjected to undernutrition, and this might indicate that ewes at late pregnancy require more metabolic adaptations to undergo energy disturbances (Duehlmeier et al., 2011).

After parturition, insulin concentrations increased during lactation. The remarkable capacities of ewes to adapt to the resulting low nutritional level in late gestation and after parturition are only possible when they have body reserves which can be utilized (Caldeira et al., 2007).

\section{Conclusions}

Incorporation of up to $30 \% \mathrm{HGW}$ in diets of Katahdin ewes (i.e., female lambs from breeding to 2 mo of their 1 st lactation) had a beneficial effect on their reproductive performance, as well as growth and development of their lambs, which are important economic factors in sheep production systems. Inclusion of HGW in diets resulted normal levels of plasma glucose, NEFA and BUN in pregnant and lactating ewes, and did not affect concentrations of serum cortisol, progesterone and insulin during gestation and lactation with the exception of cortisol at $30 \mathrm{~d}$ of gestation. These values might be indicative of an adequate balance between dietary $\mathrm{N}$ and energy. Advancing gestation caused above normal concentrations of NEFA in all diets, values which were numerically higher in HGW fed ewes. Therefore, special consideration should be given to the energy density of diets containing HGW during the last month of gestation to ensure adequate nutritional status for ewes during this period. The same consideration should be given during early lactation to favor high milk production and high lamb $\mathrm{BW}$ gain. Inclusion of HGW in diets of ewes seems to be a viable alternative to counter sustainability issues of feeding high concentrate diets. 


\title{
Conflict of interest
}

\author{
There is no conflict of interest.
}

\section{Acknowledgements}

We acknowledge that accurate assessment of the reproductive rate and metabolic profile of ewes can only be made from responses of many experimental units utilized in any research project. Thus, some caution should be used when interpreting result from our study due to the limited number of ewes used.

\section{References}

AOAC, 1994. Official Methods of Analysis, 14th ed. Association Official Analytical Chemists, Arlintong, VA, USA.

Al-Faraki, G.N., Al-Hashimi, M., 2012. Green fodder production and water use efficiency of some forage crops under hydroponic conditions. ISRN Agron., 5, http://dx.doi.org/10.5402/2012/924672, Article ID. 924672.

Alexandre, G., Mandonnet, N., 2005. Goat meat production in harsh environments. Small Rumin. Res. 60, 53-66.

Block, S.S., Bluter, W.R., Ehrhardt, R.A., Bell, A.W., Van Amburgh, M.E., Boiclair, Y.R., 2001. Decreased concentration of plasma leptin in periparturient dairy cows is caused by negative energy balance. J. Endocrinol. 171, 339-348.

Braun, J.P., Trumel, C., Bézille, P., 2010. Clinical biochemistry in sheep: a selected review. Small Rumin. Res. 92, 10-18.

Caldeira, R.M., Belo, A.T., Santos, C.C., Vazques, M.I., Portugal, A.V., 2007. The effect of long-term feed restriction and over-nutrition on body condition score, blood metabolites and hormonal profiles in ewes. Small Rumin. Res. 68, 242-255.

Camacho, L.E., Benavidez, J.M., Hallford, D.M., 2012. Serum hormone profiles, pregnancy rates, and offspring performance of Rambouillet ewes treated with recombinant bovine somatotropin before breeding. J. Anim. Sci. 90 (8), 2826-2835.

Caroprese, M., Albenzio, M., Marzano, A., Schena, L., annicchiarico, G., Sevi, A., 2010. Relationship beterrn Cortisol response to stress and behavior, immune profile, and production performance of dairy ewes. J. Dairy Sci. 93, 2395-2403.

Duehlmeier, R., Fluegge, I., Schwert, B., Parvizi, N., Ganter, M., 2011. Metabolic adaptations to pregnancy and lactation in German Blackheaded Mutton and Finn sheep ewes with different susceptibilities to pregnancy toxaemia. Small Rumin. Res. 96, 178-184.

Dung, D.D., Godwin, I.R., Nolan, J.V., 2010. Nutrient content and in sacco digestibility of barley grain and sprouted barley. J. Anim. Vet. Adv. 9, $2485-2492$.

Firat, A., Özpinar, A., 2002. Metabolic profile of pre-pregnancy, pregnancy and early lactation in multiple lambing zakis ewes 1 . Changes in plasma glucose, 3 hidroxy-butyrate and cortisol levels. Ann. Nutr. Metab. 46, 57-61.

Foster, J.L., Adesogan, A.T., Carter, J.N., Blount, A.R., Myer, R.O., Phatak, S.C., 2009. Intake, digestibility, and nitrogen retention by sheep supplemented with warm-season legume hays or soybean meal. J. Anim. Sci. 87 (9), 2891-2898.

Gardner, D.S., Buttery, P.J., Daniel, Z., Symonds, M.E., 2007. Factors affecting birth weight in sheep: maternal environment. Reproduction 133, 297-307.

Gebremedhin, W.K., 2015. Nutritional benefit and economic value of feeding hydroponically grown maize and barley fodder for Konkan Kanyal goats. J. Agric. Vet. Sci. 8, 24-30.

Godfrey, R.W., Dodson, R.E., 2003. Effect of supplemental nutrition around lambing on hair sheep ewes and lambs during the dry and wet season in the US Virgin Islands. J. Anim. Sci. 81, 587-593.

Hamadeh, S.K., Barbour, E., Abi Said, M., Daadaa, K., Tarraf, C.G., 1998. Reproductive performance, serum progesterone, and milk production in spring postpartum Awassi and Finn X Texel X Awassi ewes. J. Agric. Sci. 131, 347-352.

Hatfield, P.G., Head, W.A., Fitzgerald, J.A., Hallford, D.M., 1999. Effects of level of energy intake and energy demand on growth hormone, insulin, and metabolites in Targhee and Suffolk ewes. J. Anim. Sci. 77, 2757-2765.

Herrera, T.E., Cerrillo, S.M.A., Juárez, R.A.S., Murillo, O.M., Ríos, R.F.G., Reyes, E.O., Bernal, B.H., 2010. Efecto del tiempo de cosecha sobre el valor proteico y energético del forraje verde hidropónico de trigo. Interciencia 35, 1-7.

Kaneko, J.J., Harvey, J.W., Bruss, M.I., 2008. Clinical Biochemistry of Domestic Animal. Academic Press, San Diego, CA, USA.

Karapehlivan, M., Atakisi, E., Atakisi, O., Yucayurt, R., Pancarsi, S.M., 2007. Blood biochemical parameters during the lactation and dry period in Tuj ewes. Small Rumin. Res. 73, 267-271.

Kenyon, P.R., Blair, H.T., Jenkinson, C.M.C., Morris, S.T., Mackenzie, D.D.S., Peterson, S.W., Firth, E.C., Johnston, P.L., 2009. The effect of ewe size and nutritional regimen beginning in early pregnancy on ewe and lamb performance to weaning. New Zeal. J. Agric. Res. 52, 203-212.

Kiyma, Z., Alexander, B.M., Van Kirk, E.A., Murdoch, W.J., Hallford, D.M., Moss, G.E., 2004. Effects of feed restriction on reproductive and metabolic hormones in ewes. J. Anim. Sci. 82, 2548-2557.

Knott, S.A., Cummins, L.J., Dunshea, F.R., Eury, B.J., 2010. Feed efficiency and body composition are related to cortisol response to adrenocorticotropin hormone and insulin-induced hypoglycemia in rams. Domest. Anim. Endocrinol. 39, 137-146.

Lemley, C.O., Meyer, A.M., Neville, T.L., Hallford, D.M., Camacho, L.E., Maddock-Carlin, K.R., Wilmoth, T.A., Wilson, M.E., Perry, G.A., Redmer, D.A., Reynolds, L.P., Caton, J.S., Vonnahme, K.A., 2014. Dietary selenium and nutritional plane alter specific aspects of maternal endocrine status during pregnancy and lactation. Domest. Anim. Endocrinol. 46, 1-11.

Littell, R.C., Milliken, G.A., Stroup, W.W., Wolfinger, R.D., 1996. SAS ${ }^{\circledR}$ Sys-Tems for Mixed Models. SAS Inst. Inc., Cary, NC, USA.

Mandiki, S.N.M., Derycke, G., Bister, J.L., Mabon, N., Wathelet, J.P., Marlier, M., Paquay, R., 2002. Chemical changes and influences of rapeseed antinutritional factors on gestating and lactating ewes. 1. Animal performances and plasma hormones and glucose. Anim. Feed Sci. Technol. 98, 25-35.

Melaku, S., Peters, K.J., Tegegne, A., 2004. Feed intake, live weight, gain and reproductive performance of Menz ewes supplemented with Lablab purpureus, and graded levels of Leucaenapallida 14203 and Sesbaniasesban 1198. Liv. Prod. Sci. 87, 131-142.

Mertens, D.R., 1994. Regulation of forage intake. In: Fahey, G.C. (Ed.), Forage Quality Evaluation and Utilization. American Society of Agronomy, Inc, Madison, WI. USA.

Mireles, M.E.J., Rojas, H.S., Valencia, A.M.T., Gutierrez, S.I., Olivares, P.J., 2011. Empadre controlado, distribución de partos y prolificidad en ovejas de pelo en el trópico seco de Guerrero, México. REDVET 12 (11),1-12.

Moolchandani, A., Sareen, M., Vaishnav, J., 2008. Influence of restraint and isolation stress on plasma cortisol in male karakul sheep. Veterinarski Arhiv. 78, 3357-33662.

O’Doherty, J.V., Crosby, T.F., 1996. The effect of diet in late pregnancy on progesterone concentration and colostrum yield in ewes. Theriogenology 46 233-241.

Rattay, P.V., Jagusch, K.T., Duganzich, D.M., MacLean, K.S., Lynch, R.J., 1982. Influence of feeding post-lambing on ewe and lamb performance at grazing. Proc. N. Z. Soc. Anim. Prod. 42, 179-182.

Regnault, T.R.H., Oddy, H.V., Nancarrow, C., Sriskarandarajah, N., Scaramzzi, R.J., 2004. Glucose-stimulated insulin response in pregnant sheep following acute suppression of plasma non-sterified fatty acid concentrations. Reprod. Biol. Endocrinol. 2, 64-73.

Russel, A.J.F., 1984. Means of assessing the adequacy of nutrition of pregnant ewes. Livest. Prod. Sci. 11, 429-436.

SAS, 2003. SAS User Guide: Statistics. SAS Institute Inc., Cary, NC, USA.

Schneider, F.A., Hallford, D.M., 1996. Use of a rapid progesterone radio-immunoassay to predict pregnancy and fetal numbers in ewes. Sheep Goat Res. J. $12,33-38$ 
Segura, J.C., Sarmiento, L., Rojas, O., 1996. Productivity of Pelibuey and Blackbelly ewes in Mexico under extensive management. Small Rumin. Res. 21, $57-62$.

Squires, E.J., 2010. Applied Animal Endocrinology, 2nd ed. CAB International, Nosworthy Way. Wallingford. Oxforshire, UK.

Steel, R.G.D., Torrie, J.H., Dickey, D.A., 1997. Principles and Procedures of Statistics: A Biometrical Approach, 3rd ed. McGraw-Hill Co., NY, USA.

Van Soest, P.J., Robertson, J.B., Lewis, B.A., 1991. Methods for dietary, neutral detergent fiber, and non-starch polysaccharides in relation to animal nutrition. Symposium: carbohydrate methodology, metabolism, and nutritional implications in dairy cattle. J. Dairy Sci. 74, $3583-3597$.

Van Soest, P.J., 1994. Nutritional Ecology of the Ruminant, 2nd ed. Cornell University Press, Ithaca. NY. USA.

Vergara, V.I., DeLucas, T.J., Pérez, R.M.A., Arbiza, A.S., 2006. Evaluación productiva de ovejas Pelibuey, Blackbelly, Pelibuey y Dorper cruzadas con sementales Katahdin y Dorper en una explotación intensiva en México. ITA. SEOC, Zamora, pp. $247-250$.

Vonnahme, K.A., Neville, T.L., Perry, G.A., Redmer, D.A., Reynolds, L.P., Caton, J.S., 2013. Maternal dietary intake alters organ mass and endocrine and metabolic profiles in pregnant ewe lambs. Anim. Reprod. Sci. 141, 131-141. 